\title{
Antibiotic resistance rates of Pseudomonas aeruginosa, Acinetobacter baumannii and Klebsiella pneumoniae isolated from a university-affiliated hospital in North Cyprus
}

\section{Kuzey Kıbrıs'taki bir üniversite hastanesinden izole edilen Pseudomonas aeruginosa, Acinetobacter baumannii ve Klebsiella pneumoniae bakterilerinin antibiyotik direnç oranları}

Emrah RUH ${ }^{1}$, Umut GAZi ${ }^{1}$, Meryem GÜVENiR ${ }^{2}$, Kaya SÜER ${ }^{3}$, Nedim ÇAKIR ${ }^{3}$

\section{ABSTRACT}

Objective: Infections caused by resistant gramnegative bacteria to antimicrobials occur at increasing rates. Therefore, routine screening of resistance patterns is crucial for treatment approaches using proper antibiotics. Nevertheless, there is not enough data with respect to antibiotic resistance profiles in North Cyprus. This study was conducted in order to investigate the resistance rates of Pseudomonas aeruginosa, Acinetobacter baumannii and Klebsiella pneumoniae which were isolated from the Near East University (NEU) Hospital, North Cyprus.

Method: It was included in this study $P$. aeruginosa, $A$. baumannii and $K$. pneumoniae which were isolated in the NEU Hospital Clinical Microbiology Laboratory between 01 August 2010 and 31 December 2014. Identification and susceptibility tests were performed by using the BD Phoenix 100 system (software version 6.01A). The antimicrobial susceptibility test results were determined according to the Clinical and Laboratory Standards Institute (CLSI) guidelines, and the resistance rates of bacterial isolates to antibiotics were examined retrospectively.

Results: It was evaluated that the antibiotic resistance rates of $186 P$. aeruginosa, $61 \mathrm{~A}$. baumannii, and $204 \mathrm{~K}$. pneumoniae strains which were isolated

\section{ÖZET}

Amaç: Antimikrobiyallere dirençli Gram-negatif bakterilere bağlı gelișen enfeksiyonlar gittikçe artan oranlarda görülmektedir. Bu nedenle direnç paternlerinin rutin olarak taranması tedavide uygun antibiyotik verilmesi için önemlidir. Ancak, Kuzey Kıbrıs'taki antibiyotik direnç profiline ilișkin yeterli veri mevcut değildir. Bu çalıșma Kuzey Kıbrıs'taki Yakın Doğu Üniversitesi (YDÜ) Hastanesi'nde izole edilen Pseudomonas aeruginosa, Acinetobacter baumannii ve Klebsiella pneumoniae bakterilerindeki direnç oranlarının araștırııması amacıyla yapılmıștır.

Yöntem: YDÜ Hastanesi Klinik Mikrobiyoloji Laboratuvarı'nda 01.08.2010 ve 31.12.2014 tarihleri arasında izole edilen $P$. aeruginosa, $A$. baumannii ve $K$. pneumoniae bakterileri bu çalıșmaya dâhil edilmiștir. Tanımlama ve duyarılık testleri BD Phoenix 100 sistemi (6.01A yazılım programı) kullanılarak yapılmıștır. Antimikrobiyal duyarlılık test sonuçları Clinical and Laboratory Standards Institute (CLSI) kılavuzuna göre belirlenmiș ve bakteri izolatlarının antibiyotiklere direnç oranları retrospektif olarak incelenmiștir.

Bulgular: YDÜ Hastanesi'nde Ağustos 2010 ve Aralık 2014 tarihleri arasinda izole edilen 186 P. aeruginosa, $61 \mathrm{~A}$. baumannii, ve $204 \mathrm{~K}$. pneumoniae

\footnotetext{
'Near East University Faculty of Medicine, Department of Medical Microbiology and Clinical Microbiology, Nicosia, TRNC ${ }^{2}$ Near East University, Vocational School of Health Services, Nicosia, TRNC

${ }^{3}$ Near East University Faculty of Medicine, Department of Clinical Microbiology and Infectious Diseases, Nicosia, TRNC
}

DOI ID : 10.5505/TurkHijyen.2016.82653

Ruh E, Gazi U, Guvenir M, Suer K, Cakır N. Antibiotic resistance rates of Pseudomonas aeruginosa, Acinetobacter baumannii and Klebsiella pneumoniae isolated from a university-affiliated hospital in North Cyprus Turk Hij Den Biyol Derg, 2016; 73(4): 333-344 
between August 2010 and December 2014 at the NEU Hospital. P. aeruginosa isolates were mostly resistant to aztreonam (42.9\%), ceftazidime (19.5\%), levofloxacin (20.2\%) and ciprofloxacin (18.8\%). In contrary, resistance rates for imipenem and meropenem were lower $(11.8 \%$ and $6.5 \%$, respectively). A. baumannii displayed high resistance $(32.8 \%-92.7 \%)$ to most of the antibiotics tested, while the resistance rate for colistin was $5.1 \%$. The highest antimicrobial resistance rates in K. pneumoniae isolates were detected in ampicillinsulbactam (39.9\%), cefazolin (35.3\%), cefuroxime (34.2\%) and tetracycline $(30.8 \%)$; while the lowest rates of resistance were recorded for ertapenem (4.6\%), imipenem $(0.0 \%)$, meropenem $(1.0 \%)$ and amikacin $(0.0 \%)$. Besides, extended-spectrum beta-lactamase (ESBL) positive results were obtained among $16.7 \%$ of $K$. pneumoniae isolates.

Conclusion: According to literature review, this is the first study that evaluated the antimicrobial resistance rates of $P$. aeruginosa, $A$. baumannii and $K$. pneumoniae isolates in a centre in North Cyprus. Among the antibiotics tested, particularly the carbapenem resistance in $P$. aeruginosa and $K$. pneumoniae strains, and colisitin resistance in $A$. baumannii were detected at lower rates in comparison to the other studies where high rates of resistance were documented. Nevertheless, the results of this study indicate that antibiotic resistance in our hospital cannot be ignored, and the test results should be monitored routinely. By conducting multi-centered studies, more comprehensive data on antimicrobial resistance patterns and the underlying genetic mechanisms should be documented in North Cyprus.

Key Words: drug resistance, North Cyprus Pseudomonas aeruginosa, Acinetobacter baumannii, Klebsiella pneumoniae sușunun antibiyotik direnç oranları değerlendirilmiștir. $P$. aeruginosa izolatlarında en yüksek direnç oranları aztreonam $(\% 42,9)$, seftazidim $(\% 19,5)$, levofloksasin $(\% 20,2)$ ve siprofloksasin $(\% 18,8)$ antibiyotiklerinde görülmüștür. İmipenem ve meropenem için ise daha düșük direnç oranları (sırasıyla \%11,8 ve \%6,5) saptanmıștır. A. baumannii izolatlarının, test edilen antibiyotiklerin çoğuna karşı yüksek seviyede dirençli $(\% 32,8-\% 92,7)$ olduğu görülmüș; bu izolatlar arasındaki kolistin direnci ise $\% 5,1$ olarak belirlenmiștir. $K$. pneumoniae izolatlarında en yüksek direnç oranları ampisilinsulbaktam $(\% 39,9)$, sefazolin $(\% 35,3)$, sefuroksim $(\% 34,2)$ ve tetrasiklin $(\% 30,8)$ antibiyotiklerinde; en düşük oranlar ise ertapenem $(\% 4,6)$, imipenem $(\% 0,0)$, meropenem $(\% 1,0)$ ve amikasin $(\% 0,0)$ antibiyotiklerinde saptanmıștır. Ayrıca, K. pneumoniae izolatları arasında $\% 16,7$ oranında genișlemiș spektrumlu beta-laktamaz (GSBL) pozitifliği görülmüștür.

Sonuç: Bu çalıșma, araștırmalarımıza göre Kuzey Kıbris'taki bir merkezde $P$. aeruginosa, $A$. baumannii ve K. pneumoniae izolatlarının antibiyotiklere karșı direnc oranlarını değerlendiren ilk çalıșmadır. Çalıșmamızda, test edilen antibiyotikler arasında özellikle $P$. aeruginosa ve $K$. pneumoniae sușlarında karbapenem direnci; A. baumannii'de ise kolistin direnci, yüksek direnç oranlarının bildirildiği diğer çalıșmalara göre daha düșük oranlarda bulunmuștur. Ancak, bu çalıșmanın bulguları hastanemizde antibiyotik direncinin gözardı edilmemesi ve test sonuçlarının rutin olarak taranması gerektiğine işaret etmektedir. Çok merkezli çalıșmalar yürütülerek Kuzey Kıbrıs'taki antimikrobiyal direnç paternleri ve altta yatan genetik mekanizmalar ile ilgili daha geniş kapsamlı verilerin elde edilmesi gerekmektedir.

Anahtar Kelimeler: ilaç direnci, Kuzey Kıbrıs Pseudomonas aeruginosa, Acinetobacter baumannii, Klebsiella pneumoniae

\section{INTRODUCTION}

Infections developed by antibiotic-resistant Gram-negative bacteria occur at increasing rates. Apart from being difficult to treat, these infections are associated with high morbidity and mortality and pose a threat to the global public health (1).
Due to the presence of outer membrane structure and defense mechanisms such as periplasmic betalactamases, Gram-negative bacteria are more resistant to antimicrobial agents than Gram-positive bacteria. This also makes it more difficult to develop 
novel antibiotics against Gram-negative bacteria (2).

Pseudomonas aeruginosa is a non-fermenting Gram-negative bacterium which is an opportunistic pathogen (3). This bacterium, which causes nosocomial infections such as pneumonia, urinary tract infection and sepsis, is resistant to many antibiotics including beta-lactams, aminoglycosides and fluoroquinolones (4). Infections caused by multidrug-resistant $P$. aeruginosa are regarded as a serious clinical problem and are seen relatively common (5).

Acinetobacter baumannii is a non-fermenting Gram-negative bacterium and this opportunistic pathogen is generally isolated from the infections in intensive care units (6). A. baumannii has been recognised as an important cause of nosocomial infections with high morbidity and mortality rates (7). This bacterium is most commonly encountered in septicemia, pneumonia and urinary tract infections (8). A. baumannii is capable of developing resistance against antimicrobial agents, and there has been an increase in the rates of multidrug-resistant isolates in the last decade (6).

Gram-negative bacteria that belong to Enterobacteriaceae, are part of the normal intestinal flora and besides, are among the most commonly encountered pathogens in clinical practice. These bacteria can easily be transmitted between individuals and they tend to receive genetic information typically by plasmids and transposons (9). Klebsiella pneumoniae, a member of Enterobacteriaceae, is an opportunistic pathogen and is involved in septicemia, pneumonia, urinary tract infections and soft tissue infections among hospitalized and immunosuppressed patients. Multidrug-resistance in K. pneumoniae is generally caused by the production of extended-spectrum beta-lactamases (ESBL) and carbapenemases. The spread of multidrug-resistant isolates usually results in the failure of antibiotic therapy given for these infections (10).

In order to control the infections caused by resistant Gram-negative bacteria, the risk factors should be determined, the resistant isolates should be identified, and preventive measures should be taken. Determination of the local antibiotic resistance profiles can guide the options of empirical therapy for the antibiotic-resistant Gram-negative infections (1).

There have been many publications on antimicrobial drug resistance in the literature. However the resistance patterns of $P$. aeruginosa, A. baumannii and K. pneumoniae strains in North Cyprus remain unclear. For this reason, $P$. aeruginosa, $A$. baumannii and $K$. pneumoniae isolates which were reported between August 2010 and December 2014 at the Near East University (NEU) Hospital in North Cyprus were included in this study. Therefore, a data on the antibiotic resistance patterns of these important bacteria isolated from the NEU Hospital was obtained in this research.

\section{MATERIAL and METHOD}

The present study was conducted at the NEU Hospital Clinical Microbiology Laboratory. The NEU Hospital was established in Nicosia, capital of North Cyprus, in July 2010. During the period of August 2010 and December 2014, the bed capacity of the hospital was 120 and the occupancy rate was $50 \%$. The 12-bed general intensive care unit and six-bed cardiovascular surgery intensive care unit had an occupancy rate of $50 \%$. Bacterial isolates, $P$. aeruginosa, $A$. baumannii and $K$. pneumoniae which were isolated at the NEU Hospital Clinical Microbiology Laboratory between 01.08.2010 and 31.12.2014 were included in this study. The isolated bacteria were collected from specimens sent by various departments during this time period. Identification of bacterial isolates and the antimicrobial susceptibility testing were performed using the BD Phoenix 100 system (software version 6.01A). The susceptibility test results were determined according to the Clinical and Laboratory Standards Institute (CLSI) guidelines (11). The presence of ESBL among $K$. pneumoniae isolates was also evaluated according to the test 
results obtained from the Phoenix instrument. Demographic information of the patients, types of clinical specimens bacteria were isolated from, and the antibiotic resistance rates were investigated retrospectively. Repetitive isolates which were recovered from identical specimens of the same patient in a short period of time were excluded from the study. However, repetitive strains isolated over an extended period of time were included in the study. In addition, strains isolated from different specimens of the same patient were also included in the study. The data obtained were analyzed using the Microsoft Excel software.

\section{RESULTS}

Two hundred and twenty-four $P$. aeruginosa, 79 A. baumannii and 229 K. pneumoniae strains were isolated at the NEU Hospital Clinical Microbiology Laboratory between 01.08.2010 and 31.12.2014. The repetitive isolates recovered in a short period of time were excluded from the analysis, thus $186 P$. aeruginosa, $61 \mathrm{~A}$. baumannii and $204 \mathrm{~K}$. pneumoniae strains were evaluated in the study. Distribution of the bacterial isolates among the patient specimens is given in the Table 1.

Demographic information of the patients and the antibiotic resistance rates of $P$. aeruginosa, $K$. pneumoniae and $A$. baumannii were identified. The findings were stated individually for each pathogen.

One hundred and eighty-six $P$. aeruginosa isolates were detected from 123 patients. Distribution of the patients according to the age groups were nine $(7.3 \%)$ for age zero; 14 (11.4\%) for age 1-14; six (4.9\%) for age $15-24 ; 12$ (9.8\%) for age $25-44 ; 17(13.8 \%)$ for age 45-64; and 65 (52.8\%) for age 65+. Numbers of female and male patients were noted to be 54 (43.9\%) and 69 (56.1\%), respectively.

The antibiotic resistance rates of $186 P$. aeruginosa isolates were evaluated. The highest

Table 1. Distribution of $P$. aeruginosa, K. pneumoniae and $A$. baumannii isolates according to the patient specimens (NEU Hospital 2010-2014).

\begin{tabular}{|l|c|c|c|c|c|c|}
\hline \multirow{2}{*}{ Specimen } & \multicolumn{2}{|c|}{ P. aeruginosa } & \multicolumn{2}{c|}{ A. baumannii } & \multicolumn{2}{c|}{ K. pneumoniae } \\
\cline { 2 - 7 } & $\mathrm{n}$ & $(\%)$ & $\mathrm{n}$ & (\%) & $\mathrm{n}$ \\
\hline Wound material & 34 & 18.3 & 7 & 11.5 & 9 & 4.4 \\
\hline Sputum & 25 & 13.4 & 10 & 16.4 & 18 & 8.8 \\
\hline Cerebrospinal fluid & 8 & 4.3 & - & - & - & - \\
\hline Deep tracheal aspirate & 30 & 16.1 & 24 & 39.3 & 16 & 7.8 \\
\hline Urine & 57 & 30.6 & 9 & 14.8 & 122 & 59.8 \\
\hline Blood & 15 & 8.1 & 3 & 4.9 & 24 & 11.8 \\
\hline Catheter & 9 & 4.8 & 6 & 9.8 & 10 & 4.9 \\
\hline Other & 8 & 4.3 & 2 & 3.3 & 5 & 2.5 \\
\hline Total & 186 & 100.0 & 61 & 100.0 & 204 & 100.0 \\
\hline
\end{tabular}


resistance rates were recorded against aztreonam (42.9\%), ceftazidime (19.5\%), levofloxacin (20.2\%) and ciprofloxacin (18.8\%). However, resistance rates for imipenem (11.8\%) and meropenem (6.5\%) were found to be lower (Table 2).

Sixty-one $A$. baumannii isolates were reported from 40 patients. Distribution of the patients according to the age groups were three $(7.5 \%)$ for age $1-14$; five $(12.5 \%)$ for age $15-24$; five $(12.5 \%)$ for age $25-44 ; 11(27.5 \%)$ for age $45-64$; and 16 $(40.0 \%)$ for age $65+$. There was no patient $(0.0 \%)$ in the age group zero. Number of female patients was $17(42.5 \%)$, and number of male patients was $23(57.5 \%)$.
Antimicrobial resistance rates of $61 A$. baumannii isolates were assessed. High levels of resistance $(32.8 \%-92.7 \%)$ were detected against most of the antibiotics tested. Colistin resistance among $A$. baumannii isolates was noted to be $5.1 \%$ (Table 3).

In this study, $204 \mathrm{~K}$. pneumoniae strains were isolated from 155 patients. Distribution of the patients according to the age groups were 18 $(11.6 \%)$ for age zero; seven $(4.5 \%)$ for age $1-14$; six (3.9\%) for age $15-24 ; 25$ (16.1\%) for age $25-44 ; 31$ (20.0\%) for age 45-64; and 68 (43.9\%) for age $65+$. Numbers of female and male patients were found to be $88(56.8 \%)$ and $67(43.2 \%)$, respectively.

Table 2. Antimicrobial resistance rates of $P$. aeruginosa isolates (NEU Hospital 2010-2014).

\begin{tabular}{|c|c|c|c|}
\hline \multirow{3}{*}{ The antibiotics tested } & \multicolumn{3}{|c|}{ P. aeruginosa ( $(\mathrm{n}: 186)$} \\
\hline & \multirow{2}{*}{$\begin{array}{c}\text { Number of the isolates } \\
\text { tested }\end{array}$} & \multicolumn{2}{|c|}{ Number of the resistant isolates } \\
\hline & & $\mathrm{n}$ & (\%) \\
\hline Piperacillin-tazobactam & 185 & 12 & 6.5 \\
\hline Ticarcillin-clavulanic acid & 86 & 8 & 9.3 \\
\hline Ceftazidime & 185 & 36 & 19.5 \\
\hline Cefepime & 184 & 9 & 4.9 \\
\hline Aztreonam & 184 & 79 & 42.9 \\
\hline Imipenem & 186 & 22 & 11.8 \\
\hline Meropenem & 184 & 12 & 6.5 \\
\hline Colistin & 128 & 14 & 10.9 \\
\hline Gentamicin & 185 & 23 & 12.4 \\
\hline Amikacin & 185 & 13 & 7.0 \\
\hline Ciprofloxacin & 186 & 35 & 18.8 \\
\hline Levofloxacin & 129 & 26 & 20.2 \\
\hline Norfloxacin & 57 & 8 & 14.0 \\
\hline
\end{tabular}


Table 3. Antimicrobial resistance rates of $A$. baumanii isolates (NEU Hospital 2010-2014).

\begin{tabular}{|c|c|c|c|}
\hline \multirow{3}{*}{ The antibiotics tested } & \multicolumn{3}{|c|}{ A. baumannii (n: 61) } \\
\hline & \multirow{2}{*}{$\begin{array}{c}\text { Number of the isolates } \\
\text { tested }\end{array}$} & \multicolumn{2}{|c|}{ Number of the resistant isolates } \\
\hline & & $\mathrm{n}$ & (\%) \\
\hline Ampicillin-sulbactam & 61 & 8 & 13.1 \\
\hline Piperacillin-tazobactam & 61 & 46 & 75.4 \\
\hline Ceftazidime & 61 & 48 & 78.7 \\
\hline Cefepime & 61 & 20 & 32.8 \\
\hline Cefotaxime & 55 & 51 & 92.7 \\
\hline Imipenem & 61 & 45 & 73.8 \\
\hline Meropenem & 61 & 45 & 73.8 \\
\hline Colistin & 59 & 3 & 5.1 \\
\hline Gentamicin & 61 & 44 & 72.1 \\
\hline Amikacin & 61 & 40 & 65.6 \\
\hline Tetracycline & 55 & 42 & 76.4 \\
\hline Ciprofloxacin & 61 & 47 & 77.0 \\
\hline Levofloxacin & 59 & 44 & 74.6 \\
\hline Trimethoprim-sulfamethoxazole & 61 & 44 & 72.1 \\
\hline
\end{tabular}

Resistance rates of 204 K. pneumoniae against antibiotics were analyzed. The resistance levels of these isolates varied among different antibiotics. The highest rates of resistance in $K$. pneumoniae isolates were detected against ampicillinsulbactam (39.9\%), cefazolin (35.3\%), cefuroxime (34.2\%) and tetracycline (30.8\%). The lowest rates of resistance were recorded for ertapenem (4.6\%), imipenem $(0.0 \%)$, meropenem $(1.0 \%)$ and amikacin $(0.0 \%)$ (Table 4$)$. Besides, $34(16.7 \%)$ of $204 \mathrm{~K}$. pneumoniae isolates were noted to be positive for ESBL.

\section{DISCUSSION}

Infections caused by antimicrobial-resistant microorganisms lead to higher mortality, morbidity and treatment costs than those of antibioticsusceptible pathogens (12). Besides, increase in the antimicrobial resistance can lead to ineffectiveness of the antibiotics used for the empirical therapy (2). For this reason, countries should establish data on their local antibiotic resistance profiles.

$P$. aeruginosa, $A$. baumannii and $K$. pneumoniae are Gram-negative bacteria which cause nosocomial 
Table 4. Antimicrobial resistance rates of K. pneumoniae isolates (NEU Hospital 2010-2014).

\begin{tabular}{|c|c|c|c|}
\hline \multirow{3}{*}{ The antibiotics tested } & \multicolumn{3}{|c|}{ K. pneumoniae (n: 204) } \\
\hline & \multirow{2}{*}{$\begin{array}{c}\text { Number of the isolates } \\
\text { tested }\end{array}$} & \multicolumn{2}{|c|}{ Number of the resistant isolates } \\
\hline & & $\mathrm{n}$ & (\%) \\
\hline Amoxicillin-clavulanic acid & 111 & 33 & 29.7 \\
\hline Ampicillin-sulbactam & 203 & 81 & 39.9 \\
\hline Piperacillin-tazobactam & 203 & 22 & 10.8 \\
\hline Ticarcillin-clavulanic acid & 69 & 16 & 23.2 \\
\hline Cefazolin & 201 & 71 & 35.3 \\
\hline Cefepime & 203 & 44 & 21.7 \\
\hline Cefotaxime & 26 & 4 & 15.4 \\
\hline Ceftriaxone & 170 & 38 & 22.4 \\
\hline Cefoxitin & 203 & 26 & 12.8 \\
\hline Cefuroxime & 111 & 38 & 34.2 \\
\hline Ceftazidime & 204 & 43 & 21.1 \\
\hline Aztreonam & 203 & 44 & 21.7 \\
\hline Ertapenem & 197 & 9 & 4.6 \\
\hline Imipenem & 203 & 0 & 0.0 \\
\hline Meropenem & 204 & 2 & 1.0 \\
\hline Gentamicin & 204 & 29 & 14.2 \\
\hline Amikacin & 204 & 0 & 0.0 \\
\hline Tetracycline & 26 & 8 & 30.8 \\
\hline Ciprofloxacin & 204 & 41 & 20.1 \\
\hline Levofloxacin & 95 & 16 & 16.8 \\
\hline Norfloxacin & 111 & 20 & 18.0 \\
\hline Trimethoprim-sulfamethoxazole & 204 & 63 & 30.9 \\
\hline
\end{tabular}


infections (2). The other significant feature of these bacteria is their ability to develop resistance against antibiotics $(3,10,13)$. In North Cyprus, antibiotic resistance patterns of $P$. aeruginosa, $A$. baumannii and $K$. pneumoniae isolates remain unclear. Therefore, the findings of these bacteria isolated from the NEU Hospital between August 2010 and December 2014 were analyzed retrospectively. In this period, $186 P$. aeruginosa from 123 patients, 61 A. baumannii from 40 patients, and $204 \mathrm{~K}$. pneumoniae from 155 patients were reported.

Demographic information of the patients revealed that, the pathogens in this study were isolated most commonly from the patients aged 65 and over. The prevalence of $P$. aeruginosa, $A$. baumannii and $K$. pneumoniae in the age group $65+$ was $52.8 \%, 40.0 \%$ and $43.9 \%$, respectively. The reason of greater rates of infection in this age group can be explained by the weakened immune response in the elderly people which results in increased sensitivity against the pathogens (14). The proportions of female and male patients infected with $P$. aeruginosa were $43.9 \%$ $56.1 \%$; while the percentages for $A$. baumannii were $42.5 \%-57.5 \%$, respectively. These findings were similar for both of the pathogens. Among the patients infected with $K$. pneumoniae, the rates of female and male patients were $56.8 \%$ and $43.2 \%$, respectively.

In our study, the patient specimens used for the isolation of these pathogens were also analyzed (Table 1). P. aeruginosa was mostly isolated from the urine samples $(30.6 \%)$, which was followed by wound material (18.3\%), deep tracheal aspirate (DTA) (16.1\%) and sputum (13.4\%) samples. This pathogen was also isolated from blood samples $(8.1 \%)$, and these findings were consistent with the infections where $P$. aeruginosa is commonly encountered $(4,15)$. The specimens which $A$. baumannii was mostly isolated were DTA (39.3\%), sputum $(16.4 \%)$, urine $(14.8 \%)$ and wound material (11.5\%). These findings were compatible with the previous studies where $A$. baumannii was stated to be isolated most commonly from the respiratory specimens followed by wound materials (16). In our study, K. pneumoniae was most frequently detected in urine samples $(59.8 \%)$. This is not surprising since this pathogen is the second most common cause of community-acquired urinary tract infections developed by Enterobacteriaceae (17). The other samples where $K$. pneumoniae isolates were reported were blood $(11.8 \%)$, sputum $(8.8 \%)$ and DTA (7.8\%), and these findings were consistent with the infections caused by this pathogen (10).

In the study, antimicrobial resistance patterns of $P$. aeruginosa, $A$. baumannii and $K$. pneumoniae isolates which were reported at the NEU Hospital betwen August 2010 and December 2014 were analyzed.

$P$. aeruginosa is intrinsically resistant to many antibiotics due to the presence of outer-membrane, efflux-pumps and intracellular mechanisms of antimicrobial inactivation. Although antibiotics such as carbapenems were introduced against P. aeruginosa, this organism can easily develop resistance as a result of mutations in the chromosome and acquisition of extracellular genes (3).

Data obtained in this study revealed that, the highest resistance in $P$. aeruginosa isolates was against aztreonam (42.9\%) (Table 2). This can be explained by the emergence of ESBL and/or AmpC beta-lactamase producing strains which can hydrolyse aztreonam, cephalosporins and penicillins. Aztreonam resistance in $P$. aeruginosa is an obstacle for the administration of appropriate therapy. Many studies from Turkey, Europe and other countries reported high resistance rates (32.0\%-52.0\%) against aztreonam (18-20).

In the present study, aminoglycoside (gentamicin: 12.4\%; amikacin 7.0\%), fluoroquinolone (ciprofloxacin: 18.8\%; levofloxacin: 20.2\%; norfloxacin: 14.0\%) and ceftazidime (19.5\%) resistance among $P$. aeruginosa isolates were 
found similar with the rates documented in the antimicrobial resistance report of South Cyprus in 2010 (21). The only difference between the findings was observed for the carbapenem antibiotics. Resistance rate in the 2010 report was declared to be $29.2 \%$, while the percentages for imipenem and meropenem resistance in this study were found $11.8 \%$ and $6.5 \%$, respectively (Table 2 ). In a recent metaanalysis from Turkey, $P$. aeruginosa isolates were reported to have decreased resistance rates to all antibiotics tested, with the exception of cefepime and monobactam, during 2010-2013 in comparison with the period before 2013 (22).

Apart from being intrinsically resistant to many antibiotics, $A$. baumannii has the ability to develop resistance against most antimicrobial agents. Presence of the outer-membrane, alteration of the drug target, enzymatic degradation of the antibiotics, and the efflux-pumps are responsible for the antimicrobial resistance (13).

In our study, $A$. baumannii isolates exhibited high resistance $(32.8 \%-92.7 \%)$ against most of the antimicrobial agents tested (Table 3 ). This finding is consistent with those of many other studies where A. baumannii was shown to develop resistance to most of the antibiotics (23-27). In this study, the lowest resistance rates in $A$. baumannii isolates were detected for colistin (5.1\%) and ampicillinsulbactam (13.1\%) (Table 3).

Among the antimicrobial agents used for $A$. baumannii, colistin is the most active antibiotic. However, because of increased incidence of colistin resistant $A$. baumannii isolates, today there is a suspicion regarding the use of this antibiotic against the infections caused by A. baumanii (28). Colistin resistance in our study was $5.1 \%$. Nevertheless, this result should be confirmed by alternative methods (11). In the literature, varying rates of colistin resistance (as high as $40.6 \%$ ) in $A$. baumannii isolates were documented by different countries (29). On the other hand, ampicillin-sulbactam is an alternative drug for $A$. baumannii infections (30). The resistance rate $(13.1 \%)$ in this study was much lower than the result (51.6\%) obtained from European countries which was published in 2008 (31).

Nearly $10 \%$ of the nosocomial infections are developed by $K$. pneumoniae. Multidrug-resistance caused most commonly by ESBLs and carbapenemases in this pathogen generally results in treatment failure (10). ESBLs which belong to Ambler Class A beta-lactamases can hydrolyse monobactams and cephalosporins, but do not affect carbapenems or cephamycins (15). Rate of infections particularly caused by ESBL producing $E$. coli and $K$. pneumoniae has increased (32). On the other hand, carbapenems have been used as the last resort treatment for the infections caused by multidrug-resistant Enterobacteriaceae (33). However, the incidence of carbapenemase-producing Enterobacteriaceae has risen globally over the last decade. K. pneumoniae carbapenemase (KPC) enzymes (for which $K$. pneumoniae isolates are the major sources) are the most frequent cause of antibiotic resistance in carbapenemase-producing Enterobacteriaceae (34).

Antibiotic resistance rates detected among $\mathrm{K}$. pneumoniae in this study were noted to be different from the data of South Cyprus in the 2010 report (21). In that publication, resistance of $K$. pneumoniae against fluoroquinolones, carbapenems and the third-generation cephalosporins were documented as $38.8 \%, 16.4 \%$, and $34.3 \%$ respectively, while the isolates in our study exhibited lower resistance rates for these antibiotics. In our $K$. pneumoniae isolates, ciprofloxacin, levofloxacin and norfloxacin resistance were recorded as $20.1 \%, 16.8 \%$ and $18.0 \%$, respectively. While low levels of resistance were detected for ertapenem and meropenem $(4.6 \%$ and $1.0 \%$, respectively), none of $K$. pneumoniae isolates $(0.0 \%)$ were resistant against imipenem. Among the third-generation cephalosporins, prevalence of resistance for cefotaxime, ceftriaxone and ceftazidime were found to be $15.4 \%, 22.4 \%$ and $21.1 \%$, 
respectively. Resistance rate of $K$. pneumoniae isolates against azteronam was $21.7 \%$ (Table 4 ). In this study, the data from Phoenix instrument revealed that $34(16.7 \%)$ of 204 K. pneumoniae isolates were positive for ESBL. However, this result should be confirmed by alternative methods (35). Yet, our finding is comparable with the data reported from Turkey in 2008. In that study, ESBL prevalence among Klebsiella spp. isolated from urine cultures was found to be $12.0 \%$ (36).

The antimicrobial resistance report in 2010 indicated that aminoglycoside resistance of $K$. pneumoniae in South Cyprus was 19.4\% (21). According to the results of our study, gentamicin resistance among $K$. pneumoniae isolates was found to be $14.2 \%$, while none $(0.0 \%)$ of these isolates was resistant to amikacin. The highest levels of resistance in $K$. pneumoniae isolates were detected for ampicillin-sulbactam (39.9\%), cefazolin (35.3\%), cefuroxime (34.2\%) and tetracycline (30.8\%) (Table 4 ). Because of the increased incidence of cefazolin resistance, today there is a suspicion regarding the use of this antibiotic against the infections caused by Enterobacteriaceae (37). Besides, a study conducted in the USA revealed an increase in the resistance rates of $K$. pneumoniae isolates against antibiotics except for tetracycline between 1998 and 2010 (38).
Our study presented a data on the antimicrobial resistance rates of $P$. aeruginosa, $A$. baumannii and K. pneumoniae isolates reported between August 2010 and December 2014 at the NEU Hospital in North Cyprus. These bacteria are clinically important pathogens and investigation of their antimicrobial resistance patterns is crucial. To our knowledge, this is the first study that analyzed the antimicrobial resistance rates of $P$. aeruginosa, $A$. baumannii and $K$. pneumoniae isolates in a centre from North Cyprus. Among the antibiotics tested, particularly the rates of carbapenem resistance in $P$. aeruginosa and $K$. pneumoniae isolates, and the level of colistin resistance in $A$. baumannii were found to be lower in comparison with the other studies where high rates of resistance were reported. Relatively lower rates of resistance in these bacteria could be a result of implementation of accurate infection control programme and administration of proper antibiotic treatment protocols in our hospital. Yet, the results obtained from this study suggest that antibiotic resistance in our hospital cannot be ignored and the susceptibility test results should be analyzed regularly. By additional multi-centered studies, more comprehensive data on antimicrobial resistance profiles of bacteria and the genetic backgrounds of resistance should be reported from North Cyprus.

\section{ACKNOWLEDGEMENTS}

This study was presented as a poster (PS-014) at the $30^{\text {th }}$ ANKEM Congress (May 2015, T.R.N.C.). 


\section{REFERENCES}

1. Kaye K, Pogue J. Infections caused by resistant Gram-negative bacteria: Epidemiology and Management. Pharmacotherapy, 2015; 35(10): 949-62.

2. Livermore DM. Current epidemiology and growing resistance of Gram-negative pathogens. Korean J Intern Med, 2012; 27(2): 128-42.

3. Morita Y, Tomida J, Kawamura Y. Responses of Pseudomonas aeruginosa to antimicrobials. Front Microbiol, 2014; 4: 422.

4. Lin SP, Liu MF, Lin CF, Shi ZY. Phenotypic detection and polymerase chain reaction screening of extended-spectrum B-lactamases produced by Pseudomonas aeruginosa isolates. J Microbiol Immunol Infect, 2012; 45: 200-7.

5. Vitkauskiene A, Skrodeniene E, Dambrauskiene A, Bakšyte G, Macas A, Sakalauskas R. Characteristics of carbapenem-resistant Pseudomonas aeruginosa strains in patients with ventilator-associated pneumonia in intensive care units. Medicina (Kaunas), 2011; 47(12): 652-6.

6. Opazo A, Domínguez M, Bello H, Amyes SGB, González-Rocha G. OXA-type carbapenemases in Acinetobacter baumannii in South America. J Infect Dev Ctries, 2012; 6(4): 311-6.

7. Zarrilli R, Pournaras S, Giannouli M, Tsakris A. Global evolution of multidrug-resistant Acinetobacter baumannii clonal lineages. Int J Antimicrob Agents, 2013; 41: 11-9.

8. Poirel L, Nordmann P. Carbapenem resistance in Acinetobacter baumannii: Mechanisms and epidemiology. Clin Microbiol Infect, 2006; 12(9): 826-36.

9. Nordmann P, Dortet L, Poirel L. Carbapenem resistance in Enterobacteriaceae: Here is the storm! Trends Mol Med, 2012; 18(5): 263-72.

10. Eftekhar F, Naseh Z. Extended-spectrum b -lactamase and carbapenemase production among burn and non-burn clinical isolates of Klebsiella pneumoniae. Iran J Microbiol, 2015; 7(3): 144-9.

11. CLSI. Clinical and Laboratory Standards Institute. Performance Standards for Antimicrobial Susceptibility Testing; Twenty-Fourth Informational Supplement - M100-S24. 2014.
12. Tang SS, Apisarnthanarak A, Hsu LY. Mechanisms of B-lactam antimicrobial resistance and epidemiology of major community- and healthcare-associated multidrug-resistant bacteria. Adv Drug Deliv Rev, 2014; 78: 3-13.

13. Nowak $P$, Paluchowska $P$, Budak A. Distribution of blaOXA genes among carbapenem-resistant Acinetobacter baumannii nosocomial strains in Poland. New Microbiol, 2012; 35(3): 317-25.

14. Gavazzi G, Krause K-H. Ageing and infection. Lancet Infect Dis, 2002; 2(11): 659-66.

15. Hakemi Vala $M$, Hallajzadeh $M$, Hashemi $A$, Goudarzi H, Tarhani M, Sattarzadeh Tabrizi M, et al. Detection of Ambler class A, B and D B-lactamases among Pseudomonas aeruginosa and Acinetobacter baumannii clinical isolates from burn patients. Ann Burns Fire Disasters, 2014; 27(1): 8-13.

16. Abdalhamid $B$, Hassan $H$, Itbaileh A, Shorman M. Characterization of carbapenem-resistant Acinetobacter baumannii clinical isolates in a tertiary care hospital in Saudi Arabia. New Microbiol, 2014; 37(1): 65-73.

17. Martin D, Fougnot S, Grobost F, Thibaut-Jovelin $S$, Ballereau F, Gueudet T, et al. Prevalence of extended-spectrum beta-lactamase producing Escherichia coli in community-onset urinary tract infections in France in 2013. J Infect, 2016; 72(2): 201-6.

18. Obritsch MD, Fish DN, MacLaren R, Jung $R$. National surveillance of antimicrobial resistance in Pseudomonas aeruginosa isolates obtained from intensive care unit patients from 1993 to 2002. Antimicrob Agents Chemother, 2004; 48(12): 4606 10.

19. Gutiérrez $O$, Juan $C$, Cercenado E, Navarro F, Bouza E, Coll P, et al. Molecular epidemiology and mechanisms of carbapenem resistance in Pseudomonas aeruginosa isolates from Spanish hospitals. Antimicrob Agents Chemother, 2007; 51(12): 4329-35.

20. Santoro DO, Romao CM, Clementino MM. Decreased aztreonam susceptibility among Pseudomonas aeruginosa isolates from hospital effluent treatment system and clinical samples. Int J Environ Health Res, 2012; 22(6): 560-70. 
21. European Centre for Disease Prevention and Control. Antimicrobial resistance surveillance in Europe 2010. Annual Report of the European Antimicrobial Resistance Surveillance Network (EARS-Net). 2011. Stockholm: ECDC.

22. Aykan ȘB, Çiftci ï. Changes in antibiotic resistance of Pseudomonas aeruginosa isolates over the past 11 years in Turkey: a meta-analysis. Mikrobiyol Bul, 2015; 49(3): 352-65.

23. Samonis G, Maraki S, Vouloumanou EK, Georgantzi GG, Kofteridis DP, Falagas ME. Antimicrobial susceptibility of non-fermenting Gram-negative isolates to isepamicin in a region with high antibiotic resistance. Eur J Clin Microbiol Infect Dis, 2012; 31(11): 3191-8.

24. Agodi A, Zarrilli R, Barchitta M, Anzaldi A, Di Popolo A, Mattaliano A, et al. Alert surveillance of intensive care unit-acquired Acinetobacter infections in a Sicilian hospital. Clin Microbiol Infect, 2006; 12(3): 241-7.

25. Japoni S, Farshad S, Abdi Ali A, Japoni A. Antibacterial Susceptibility Patterns and CrossResistance of Acinetobacter, Isolated from Hospitalized Patients, Southern Iran. Iran Red Crescent Med J, 2011; 13(11): 832-6.

26. Perez F, Hujer AM, Hujer KM, Decker BK, Rather $\mathrm{PN}$, Bonomo RA. Global challenge of multidrugresistant Acinetobacter baumannii. Antimicrob Agents Chemother, 2007; 51: 3471-84.

27. Güven T, Yilmaz G, Güner HR, Kaya Kalem A, Eser $F$, Tașyaran MA. Increasing resistance of nosocomial Acinetobacter baumannii: Are we going to be defeated Turkish J Med Sci, 2014; 44(1): 73-8.

28. Chen $Z$, Chen $Y$, Fang $Y$, Wang $X$, Chen $Y$, Qi Q, et al. Meta-analysis of colistin for the treatment of Acinetobacter baumannii infection. Sci Rep, 2015; 5(1): 17091

29. Cai Y, Chai D, Wang R, Liang B, Bai N. Colistin resistance of Acinetobacter baumannii: Clinical reports, mechanisms and antimicrobial strategies. J Antimicrob Chemother, 2012; 67(7): 1607-15.
30. Betrosian AP, Frantzeskaki F, Xanthaki A, Georgiadis G. High-dose ampicillin-sulbactam as an alternative treatment of late-onset VAP from multidrug-resistant Acinetobacter baumannii. Scand J Infect Dis, 2007; 39: 38-43.

31. Souli M, Galani I, Giamarellou H. Emergence of extensively drug-resistant and pandrug-resistant Gram-negative bacilli in Europe. Euro Surveill, 2008; 13(47): pii=19045.

32. Kumar M, Dutta R, Saxena S, Singhal S. Risk Factor Analysis in Clinical Isolates of ESBL and MBL (Including NDM-1) Producing Escherichia coli and Klebsiella Species in a Tertiary Care Hospital. J Clin Diagn Res, 2015; 9(11): DC08-13.

33. Eser OK, Altun Uludağ H, Ergin A, Boral B, Şener B, Hasçelik G. Carbapenem resistance in ESBL positive Enterobacteriaceae isolates causing invasive infections. Mikrobiyol Bul, 2014; 48(1): 59-69.

34. Falagas ME, Lourida P, Poulikakos $\mathrm{P}$, Rafailidis PI, Tansarli GS. Antibiotic treatment of infections due to carbapenem-resistant Enterobacteriaceae: systematic evaluation of the available evidence. Antimicrob Agents Chemother, 2014; 58(2): 654-63.

35. Fisher MA, Stamper PD, Hujer KM, Love Z, Croft $A$, Cohen $S$, et al. Performance of the Phoenix bacterial identification system compared with disc diffusion methods for identifying extendedspectrum beta-lactamase, AmpC and KPC producers. J Med Microbiol, 2009; 58(6): 774-8.

36. Akyar I. Antibiotic resistance rates of extended spectrum beta-lactamase producing Escherichia coli and Klebsiella spp. strains isolated from urinary tract infections in a private hospital. Mikrobiyol Bul, 2008; 42: 713-5.

37. Turnidge JD. Cefazolin and Enterobacteriaceae: Rationale for revised susceptibility testing breakpoints. Clin Infect Dis, 2011; 52(7): 917-24.

38. Sanchez GV, Master RN, Clark RB, Fyyaz M, Duvvuri P, Ekta G, et al. Klebsiella pneumoniae antimicrobial drug resistance, United States, 19982010. Emerg Infect Dis, 2013; 19(1): 133-6. 